\title{
Cultura visual. La pregunta por la imagen
}

\author{
MARTÍNEZ LUNA, Sergio \\ Sans Soleil Ediciones, Vitoria-Gasteiz, 2019 \\ ISBN: 978-84-12-00973-6
}

La agnosia visual no permite a los que la sufren reconocer aquello que están viendo. ¿Cómo debemos afrontar la cuestión de la imagen en un mundo hiperpoblado por ellas, pero que, al tiempo, en ocasiones aparenta padecer agnosia y no entenderlas? De forma figurada, se puede decir que Sergio Martínez Luna lucha contra dicha enfermedad, por supuesto no contra ella en cuanto a patología fisiológica individual, pero sí en cuanto fenómeno cultural.

El autor de Cultura visual ofrece herramientas para entender mejor cómo funcionan las imágenes. En un ensayo muy valioso para entender los temas más relevantes en los últimos lustros de teoría respecto a esta cuestión, Martínez Luna dota de herramientas para que el lector conozca mejor la cultura referida a ese ámbito, en unas sociedades que las utilizan en abundancia.

La investigación esboza de manera indirecta una ontología de la imagen, pretende analizarla en cuanto a ella misma, evita que le suceda aquello que ha acabado ocurriendo en tantos estudios visuales, muy influidos por los estudios culturales, en los que la imagen acaba siendo una mera excusa para la información política o social contenida en ella. Pero la imagen, más allá de sus referidas elecciones de representación, de qué ha escogido mostrar en cuanto al conocimiento, o de cómo defienda o ataque a cierto poder, posee fuerza en sí misma, se inscribe en sus propias coordenadas, muchas de las cuales se desgranan en este ensayo.

Igualmente, se opta por describir su funcionamiento sin esbozar con ello un canon histórico, una jerarquización y una tipología; por ello, en el texto se presta mucha atención a aquellos tipos que han quedado al margen de los discursos normativos, más allá, por tanto, de aquellas estimadas como valiosas dentro de los mencionados cánones.

Pero analizar su funcionamiento no excluye de interesarse por sus usos. Martínez Luna indaga en la visualidad
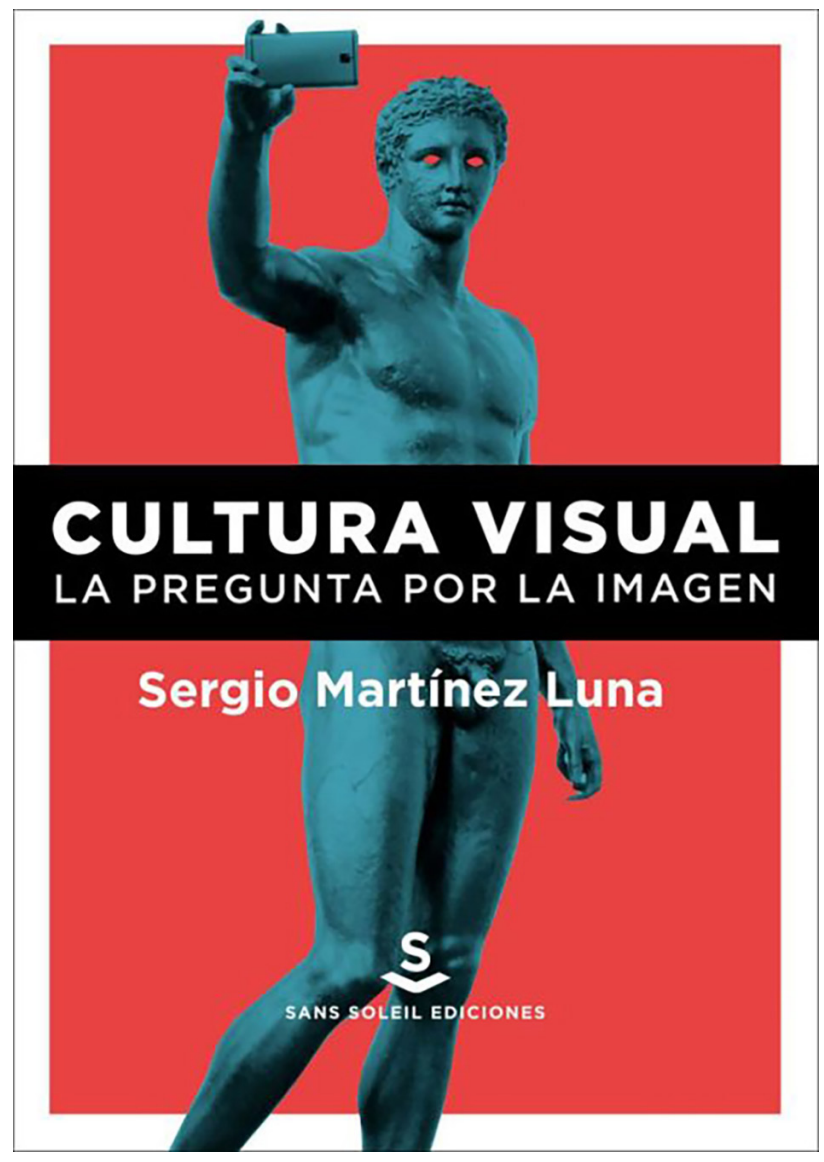

como codificación de un lenguaje sobre los actos de ver y sus modos de comunicación específicos, en una articulación de imaginarios personales en códigos colectivos, con una cultura determinada que presiona por establecer visualidades concretas. Profundiza en la relación con las imágenes (y contra ellas) de las culturas y estratos hegemónicos, pero también de las subculturas y grupos minoritarios, en su disputar y acordar condensados en imaginarios.

Cómo citar este artículo: FERRER VENTOSA, Roger, "MARTíNEZ LUNA, Sergio: Cultura visual. La pregunta por la imagen», Boletín de Arte-UMA, n. ${ }^{42}$, Departamento de Historia del Arte, Universidad de Málaga, 2021, pp. 339-341, ISSN: 0211-8483, e-ISSN: 2695-415X, DOI: http://dx.doi.org/10.24310/BoLArte.2021.vi42.11207 
Analiza la realidad visual presente, marcada por la presentación de las imágenes en formato digital y su despliegue en universos hipermediáticos, expuestas por fuentes diversas, con su espejismo de espacio abstracto interconectado, que pretende haber superado la materialidad, con las obras visuales que ya no resultan necesariamente huella del pasado, y con una fuerte capacidad de agencia sobre los individuos.

Ese festín excesivo les ha hecho perder fuerza, cada vez menos memorables. Una situación cotidiana en el mundo contemporáneo nos sitúa mirando documentos de atrocidades diversas pero rodeados por publicidad, banners, enlaces... Para evitar una relación banal con esas salvajadas documentadas visualmente, deberíamos intentar que recuperasen su poder de punctum en términos barthesianos, de conmovernos, superando la indiferencia y su instrumentalización con fines como poco espurios. Y es que la irrupción de la imagen digital ha coincidido con la curiosa sensación de final del mundo provocada por las crisis, con el ultraliberalismo y su globalización ahora puestos en tela de juicio por quien los creó.

Supuestamente la imagen digital escogió rebajar sus funciones representativas para potenciar las performativas, que pretenderían incitar a la participación en el mundo. El autor plantea dejar la dinámica favorable a la «participación», interesada y potenciada desde sectores culturales proclives al mercantilismo como único valor, por una del cuidado, la de hacerse responsable también de los demás en la red de relaciones en la que estamos entretejidos, un cuidado que evita antes que nada formar parte de la lógica del consumo y del beneficio económico.

Como puede observarse, priorizar la ontología de la imagen no implica descartar su análisis como expositora de ideas sociales o políticas, vehículo para su difusión. Por ello, Martínez Luna se pregunta también por la dimensión más fáctica, con ella incardinada en el mundo y, por tanto, cargada de valencias para determinar la organización de las sociedades actuales. ¿Qué cabe esperar de ella en ese contexto?

Las implicaciones de la nueva iconicidad cultural mediante las redes sociales ocupan una parte significativa del ensayo, con las grandes corporaciones que controlan dichas redes, los movimientos de resistencia, así como también las consecuencias políticas de ese nuevo horizonte social y las culturas y contraculturas que se derivan. En cualquier caso, según defiende el ensayista, en un mundo contemporáneo hechizado por lo apocalíptico y a la vez nostálgico de un tiempo que nunca fue, la imagen puede revelar y dotar de esperanza.

La irrupción de la imagen digital y su difusión por superficies diversas fue saludada prematuramente como enterradora de la imagen analógica. Martínez Luna ahonda tanto en la fotografía, como en el cine y en su situación en la era en que tanto hay producción visual sobre soporte de un tipo como del otro; se preocupa por ejemplo, por el lugar que el cuerpo ocupa en todas ellas, y en los nexos de unión entre los orígenes del cine para vincular el cine de tipo de atracciones con los blockbusters, así como el cine posnarrativo que retoma características de sus ancestros en los inicios del medio, por ejemplo al proponer nuevas vías no limitadas por la causalidad o la necesidad de una historia. Sea como sea, en los tiempos del cine posnarrativo, las instalaciones o cierto arte contemporáneo, el cine y la fotografía cada vez muestran unas fronteras entre ambos más difusas y difíciles de delimitar.

El recorrido por la comprensión del fenómeno icónico propuesto por Martínez Luna concluye en las imágenes en su faceta ritual, con sus derivadas mágicas, la cuestión de la agencia que poseen y su influjo en los seres humanos.

Para concluir este comentario, por lo que se refiere a las influencias de teorías de la imagen que se diría han influido en Martínez Luna, en el ensayo se nota la reflexión promovida por los estudios visuales de clásicos como W.J.T. Mitchell y José Luis Brea, así como de la Bildwissenschaft, divulgada en ámbito hispanohablante por Ana García Varas. La narratóloga Mieke Bal es otra estudiosa que ha dejado un poso en el reflexionar de Martínez Luna, con conceptos propios de los estudios literarios que Bal ha acentuado en la teoría de lo visual, como por ejemplo el valor de la focalización. En esta Cultura visual también se detectan las reflexiones generadas por la teoría cinematográfica, sobre todo aquella que estudia el cine como escultor de tiempo. Otro autor que aparece en las reflexiones propuestas es Walter Benjamin, con su teoría del peso de la experiencia como esta sufre con el capitalismo. Finalmente, citaremos a Alfred Gell, tan importante para investigar las cuestiones de la agencia en la imagen. Pero Martínez Luna toma esos influjos no para ofrecer un análisis derivativo sino como ocasio- 
nal confirmación de lo que expone, o como punto de partida de un discurrir original.

En resumen, Cultura visual resulta un estudio muy bien hilvanado, culto al tiempo que original, que sirve como panorama de algunas de las cuestiones y discusiones más candentes en la estética de las últimas décadas. Por tanto, gracias a este ensayo el lector dispondrá de más medios para contrarrestar aquella figurada agnosia visual cultural.

Roger Ferrer Ventosa Universidad de Lisboa 